\title{
Emergence and significance of carbohydrate-specific antibodies
}

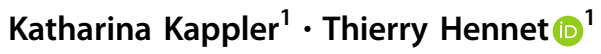

Received: 20 May 2020 / Revised: 14 July 2020 / Accepted: 22 July 2020 / Published online: 5 August 2020

(c) The Author(s), 2020. This article is published with open access

\begin{abstract}
Carbohydrate-specific antibodies are widespread among all classes of immunoglobulins. Despite their broad occurrence, little is known about their formation and biological significance. Carbohydrate-specific antibodies are often classified as natural antibodies under the assumption that they arise without prior exposure to exogenous antigens. On the other hand, various carbohydrate-specific antibodies, including antibodies to $\mathrm{ABO}$ blood group antigens, emerge after the contact of immune cells with the intestinal microbiota, which expresses a vast diversity of carbohydrate antigens. Here we explore the development of carbohydrate-specific antibodies in humans, addressing the definition of natural antibodies and the production of carbohydrate-specific antibodies upon antigen stimulation. We focus on the significance of the intestinal microbiota in shaping carbohydrate-specific antibodies not just in the gut, but also in the blood circulation. The structural similarity between bacterial carbohydrate antigens and surface glycoconjugates of protists, fungi and animals leads to the production of carbohydrate-specific antibodies protective against a broad range of pathogens. Mimicry between bacterial and human glycoconjugates, however, can also lead to the generation of carbohydrate-specific antibodies that cross-react with human antigens, thereby contributing to the development of autoimmune disorders.
\end{abstract}

\section{Structural diversity of carbohydrate antigens}

Despite their prominent occurrence at the surface of all cells and virus particles, carbohydrates do not elicit immune responses like peptide antigens. Yet, carbohydrate-specific antibodies are widespread among all classes of immunoglobulins [1]. Carbohydrate antigens eliciting an immune response represent structures consisting of monosaccharides and oligosaccharides that are foreign to the host. Although human glycoconjugates encompass a tremendous diversity of structures, human glycosylation is based on the combination of only the ten monosaccharides glucose (Glc), galactose (Gal), N-acetylglucosamine (GlcNAc), Nacetylgalactosamine (GalNAc), glucuronic acid, iduronic acid, xylose, mannose, fucose (Fuc), and the sialic acid Nacetylneuraminic acid (NeuAc) [2]. By comparison, bacterial glycosylation is based on an alphabet consisting of more than one hundred distinct monosaccharides. In addition to the ten monosaccharides found on human cells,

\footnotetext{
Thierry Hennet

thierry.hennet@uzh.ch

1 Institute of Physiology, University of Zurich, Zurich, Switzerland
}

bacterial glycans contain several deoxysugars and deoxyaminosugars, such as rhamnose, quinovose, $\mathrm{N}$ acetylrhamnosamine and $\mathrm{N}$-acetylquinovosamine, arabinose and 3-deoxy-D-manno-octulosonic acid (KDO) [3, 4]. In contrast, Fuc is the only deoxyhexose [5] and NeuAc the only sialic acid [6] found on human glycoconjugates. Beyond monosaccharide composition, carbohydrate conformations and thereby antigenic properties largely depend on the types of glycosidic linkages connecting monosaccharides. Accordingly, Glc can be recognized as a foreign antigen and elicit the production of antibodies, when it is polymerized through linkages unused in human cells, such as $\beta 1-3$ or $\beta 1-6$ found in fungal and bacterial $\beta$-glucans [7]. The multitude of combinations of monosaccharides together with a wide range of glycosidic linkages occurring in prokaryotes [8] and eukaryotes [4] yield an extensive repertoire of carbohydrate antigens susceptible to stimulate the production of antibodies in humans.

\section{Commonly recognized carbohydrate antigens}

A large pool of serum $\operatorname{IgM}$ and $\operatorname{IgG}$ recognizes a variety of carbohydrate antigens [9-12]. These most prominently recognized antigens include the monosaccharides $\alpha$-rhamnose, $\alpha$-GlcNAc and $\beta$-GlcNAc [10], and the sulfated Gal $(\beta 1-4)$ GlcNAc structure [9]. Antibodies against $\beta 4$-linked 
oligosaccharides of Glc, $\alpha-G a l$ and GlcNAc $(\beta 1-4)$ GlcNAc are also commonly observed [10]. The repertoires of carbohydrate antigens recognized show a large inter-individual variability among human beings [10, 13]. Despite the recognition of mono- and disaccharide epitopes, most circulating carbohydrate-specific antibodies bind with low specificity to larger glycoconjugates, thus preventing the occurrence of disseminated antibody-mediated inflammatory reactions and autoimmunity [9]. $\alpha$-Rhamnose is a monosaccharide antigen associated with high antibody titer in human serum [14]. This prominence is explained by the absence of rhamnose on human glycoconjugates and its widespread occurrence on microbial polysaccharides $[15,16]$. Another human xenoantigen associated with carbohydrate-specific antibodies is the sialic acid $\mathrm{N}$ glycolylneuraminic acid (NeuGc). Through the inactivation of the cytidine-monophosphate-N-acetylneuraminic acid hydroxylase gene, humans have lost the ability to produce NeuGc besides NeuAc [17]. The contact to glycoproteins containing NeuGc stimulates the production of high antibody titers toward NeuGc [18-20]. Antibodies specific for NeuGc do not cross-react with NeuAc despite the close structural similarity between both sialic acids [21] (Fig. 1a).

The two disaccharide structures $\operatorname{Gal}(\alpha 1-3) \mathrm{Gal}$ and GalNAc( $\alpha 1-3)$ GalNAc are also major epitopes recognized by carbohydrate-specific antibodies. The former disaccharide is commonly referred to as the Galili or $\alpha$-Gal epitope [22] (Fig. 1b). $\alpha$-Gal antibodies [23] make up $1 \%$ of circulating IgG in human serum [24, 25]. $\alpha$-Gal antibodies are only present in the blood of humans, apes, and old-world monkeys, because these taxa have an inactive pseudogene instead of a functional $\alpha 1-3$ Gal-transferase gene [26]. The elevated titers of circulating antibodies targeting $\mathrm{Gal}(\alpha 1-3)$ Gal explains the hyperacute rejection of grafted xenotransplants, such as pig organs, in humans [27, 28]. $\alpha-\mathrm{Gal}$ antibodies develop during the first 2 years of life [29], following the exposure to intestinal bacteria expressing the Galili epitope on their cell wall glycoconjugates. The disaccharide GalNAc $(\alpha 1-3)$ GalNAc, also called Forssman antigen [30], is another epitope that is absent from human glycans but widespread on animal cells and on bacterial glycoconjugates (Fig. 1b). Accordingly, the Forssman antigen is the carbohydrate structure associated with the highest antibody titers in humans [31, 32].

Carbohydrate-specific antibodies also include antibodies targeting polymorphic oligosaccharide structures in human beings. Various blood group systems, such as the ABO, Lewis, and $\mathrm{P}$ antigen systems, are based on the selective expression of polymorphic glycosyltransferase genes. The $A B O$ glycosyltransferase gene on human chromosome 9 comprises multiple alleles that encode either an $\alpha 1-3$ GalNAc-transferase yielding the A-antigen, or an $\alpha 1-3$
Gal-transferase yielding the B-antigen, or an inactive protein yielding the O-antigen [33] (Fig. 1c). The structural difference between the $\mathrm{A}$ and $\mathrm{B}$ antigens solely relates to the differential exchange of a hydroxyl group by an acetamido group at C2 (Fig. 1d), yet this difference and the presence of high titers of circulating antibodies against $\mathrm{ABO}$ antigens precludes the transfusion with ABOincompatible blood. Two genes on chromosome 19 are responsible for the expression of Lewis antigens in endodermal tissue, such as intestinal epithelial cells, and secretions [34]. FUT3 encodes an $\alpha 1-3 / 1-4$ Fuc-transferase, yielding the Lewis A antigen and FUT2 encodes an $\alpha 1-2$ Fuc-transferase, which adds a second Fuc residue to the Lewis A antigen, yielding the Lewis B antigen [35] (Fig. 1e). Subsequent surface presentation of Lewis A and B antigens on erythrocytes is based on the transport and incorporation of antigen-expressing glycolipids into the cell membrane. Lewis $\mathrm{X}$ and Lewis $\mathrm{Y}$ antigens, which are not defined as blood cell antigens, are synthesized by the same glycosyltransferases using a different precursor glycan [34] (Fig. 1e). The P blood group system is defined by the presence of three major glycosphingolipid antigens, P1, P, and $\mathrm{Pk}$, on human erythrocytes, resulting in five phenotypes. The two most common ones are P1 phenotype, expressing $\mathrm{P} 1, \mathrm{P}$, and $\mathrm{Pk}$ antigens and $\mathrm{P} 2$ phenotype, expressing $\mathrm{P} 1$ and $\mathrm{Pk}$ antigens [36]. The A3GALT gene on chromosome 22 encodes an $\alpha 1-4$ Gal-transferase, which adds Gal to paragloboside or lactosylceramide, resulting in $\mathrm{P} 1$ and $\mathrm{Pk}$ antigens, respectively $[37,38]$. The $\mathrm{P}$ antigen is produced by the B3GALNT1 gene, yielding a $\beta 1-3$ GalNAc-transferase 1, which adds a GalNAc to the $\mathrm{Pk}$ antigen [39] (Fig. 1f).

Carbohydrate-specific antibodies can be detected already early in life without immunization, as through infections and vaccinations. Antibodies occurring without prior immunization are often classified as natural antibodies $[40,41]$. The early colonization of the gut by bacteria right after birth [42] exposes the immune system to a wide range of novel carbohydrate antigens, which leads, for example, to the emergence of $\alpha-\mathrm{Gal}$ and ABO-specific antibodies $[25,43]$. Thus, an early immune stimulation by commensal bacteria could lead to the production of carbohydratespecific antibodies. The question arises whether all antibodies classified as natural antibodies are indeed nonantigen induced antibodies.

\section{Natural antibodies}

In contrast to antigen-specific antibodies, which are produced in a T-cell-dependent manner by mature B cells, natural antibodies are defined as pre-immune antibodies, generated without antigenic stimulation and T-cell 
Fig. 1 Commonly recognized glycan epitopes by human antibodies. a N-acetylneuraminic acid (NeuAc) and Nglycolyl-neuraminic acid (NeuGc) differ only by the occurrence of an additional hydroxyl group in NeuGc. $\mathbf{b}$ Schematic structure of Forssman and Galili antigen. Glycosidic linkages are marked using the minimal nomenclature; $\alpha 3$ for $\alpha 1-3, \beta 3$ for $\beta 1-3$ and $\beta 4$ for $\beta 1-4$. $\mathbf{c}$ Schematic structure of ABO blood group antigens. d Chemical composition of galactose (Gal) and $\mathrm{N}$ acetylgalactosamine (GalNAc) with highlighted acetamido group at $\mathrm{C} 2$. e Schematic structure of Lewis antigens Lewis A, B, X, and Y. f Structure of the $\mathrm{P}$ blood group antigens $\mathrm{Pk}, \mathrm{P}$, and $\mathrm{P} 1$.
A

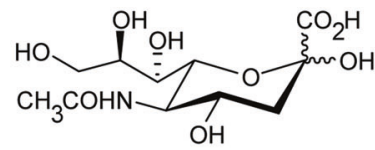

$\mathrm{N}$-acetylneuraminic acid (NeuAc)

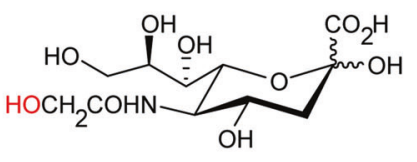

$\mathrm{N}$-glycolylneuraminic acid (NeuGc)

C

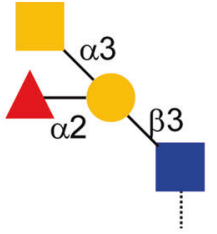

$A$ antigen

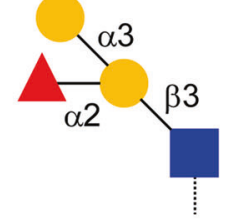

B antigen

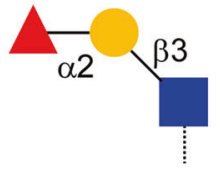

$\mathrm{O}$ antigen
B
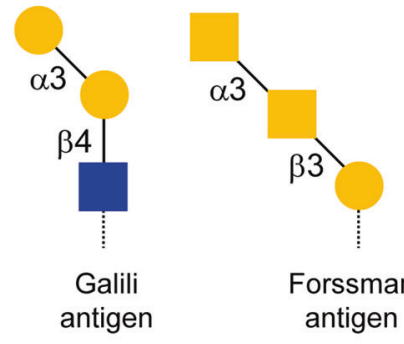

Forssman antigen
E

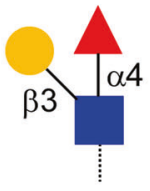

Lewis $A$

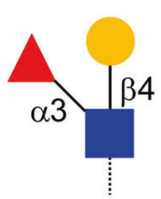

Lewis $\mathrm{X}$

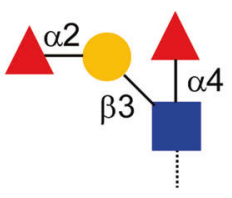

Lewis B

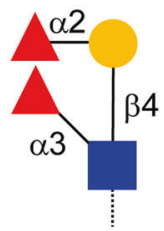

Lewis $Y$
$\mathbf{F}$

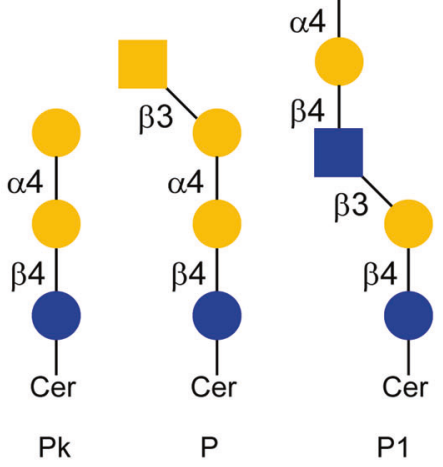

D<smiles>OC1C(O)C(O)C(O)C(O)C(O)C1O</smiles>

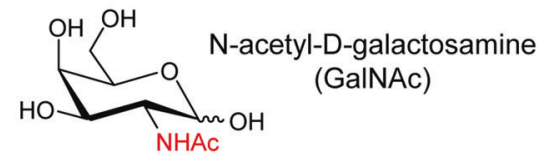

\begin{tabular}{l|l}
$\begin{array}{l}\text { Glucose } \\
\text { Glc) }\end{array}$ & $\begin{array}{l}\text { N-acetylglucosamine } \\
\text { (GlcNAc) }\end{array}$ \\
$\begin{array}{l}\text { Galactose } \\
\text { (Gal) }\end{array}$ & $\begin{array}{l}\text { N-acetylgalactosamine } \\
\text { (GalNAc) }\end{array}$
\end{tabular}

assistance [40]. Thus, natural antibodies are not strictly speaking antigen-specific, yet they contribute to protection from bacterial and viral infections by poly-reactive binding to a wide range of microbes $[44,45]$. Natural antibodies, mainly comprising antibodies of the IgM class but also $\operatorname{IgA}$ [46] and $\operatorname{IgG}[47,48]$, show low-binding affinities and occur in small amounts [40, 49]. Although natural antibodies do not undergo somatic hypermutation, a fraction of them may carry mutated variable regions, given that a low rate of hypermutation takes place even without $\mathrm{T}$-cell signals [50, 51]. Natural antibodies are produced by innatelike B cells, mainly B1 $\mathrm{CD}^{+}$cells, upon activation of Tolllike receptors [40, 41, 52].

B1 cells are defined through the combined markers $\mathrm{CD} 20^{+} \mathrm{CD} 27^{+} \mathrm{CD} 43^{+} \mathrm{CD} 70^{-}$[53] and can be $\mathrm{CD}^{+}$or $\mathrm{CD}^{-}[54,55] . \mathrm{CD}^{+} \mathrm{B} 1$ cells, also called B1a cells, are mainly produced during fetal and neonatal development from progenitors in the fetal omentum or the fetal liver, while they are generally absent in adult bone marrow. $\mathrm{CD} 5^{-}$ $\mathrm{B} 1$ cells, referred to as B1b cells, are also present in fetal 


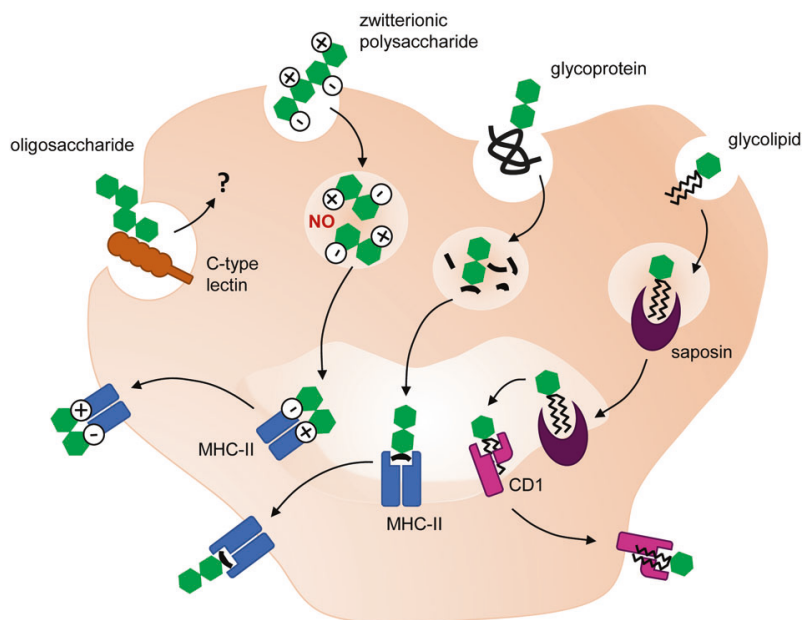

Fig. 2 Antigen processing and presentation for different types of carbohydrate structures. Extracellular glycoproteins are engulfed in endocytic or phagocytic vesicles, broken down in phagolysosomes and fragments of the glycopeptide are loaded on major histocompatibility complex II (MHC-II) to be presented at the cell surface. A similar mechanism is applied for zwitterionic polysaccharides, however, with a different processing mechanism depending on nitric oxide (NO). Glycolipids are presented on CD1-type proteins that are similar to MHC-I after being captured by lipid transfer proteins, such as saposins. The mechanisms underlying the processing and presentation of soluble oligo- and polysaccharides are unknown but are likely to involve binding through $\mathrm{C}$-type lectins expressed at the surface of antigen-presenting cells.

omentum and liver, but additionally occur in adult bone marrow, thus providing persistent maintenance of the B1cell pool [40, 54]. Conventional B cells, defined as B2 cells, in contrast, are absent from the fetal omentum. B1a cells and are typically encoded by germline $\mathrm{V}$ genes during VDJ recombination without or with a low rate of somatic hypermutation and low N-region diversity [54, 56-58]. Recent studies, however, highlighted the existence of mouse B1a cells, which produce antibodies with higher Nregion diversity and antibodies that underwent somatic hypermutation and class switching with increasing age $[59,60]$. As the levels of natural $\operatorname{IgA}$ and $\operatorname{IgG}$ but not of IgM remain low in germ-free mice [61], exposure to the gut microbiota, either through stimulation of innate immunity or through direct antigen stimulation, likely contributes to the emergence of natural IgG and IgA [40]. This explanation, however, would imply that not all natural antibodies adhere to the conventional definition as being antigenindependent.

\section{Development of carbohydrate-specific antibodies}

Despite the broad occurrence and the large variety of carbohydrate-specific antibodies, surprisingly little is known about their origin and maturation. Carbohydratespecific antibodies are traditionally believed to be induced in a T-cell-independent manner. For many years, the accepted dogma stated that carbohydrate-specific antibodies feature low affinity and specificity and are mainly confined to the IgG2 subclass in the blood [62-65]. However, recent studies described carbohydrate-specific antibodies among multiple immunoglobulin subclasses [66, 67] and demonstrated the existence of high-affinity carbohydrate-specific antibodies [68].

The pathways of antigen processing and presentation are well-established for peptide antigens. After endocytosis, peptidic antigens are broken down in phagolysosomes and fragments are presented in the groove of major histocompatibility complex (MHC)-II molecules at the cell surface (Fig. 2). MHC-II is expressed by all antigen-presenting cells, including B cells, dendritic cells, and macrophages. Intracellular antigens are processed and presented by MHCI in a similar fashion at the surface of all cell types [69]. The production of specific antibodies results from the activation of naive $\mathrm{B}$ cells in association with $\mathrm{T}$ cells providing costimulatory signals. As activated B cells proliferate and enter the germinal centers of lymphoid follicles, interaction with $\mathrm{T}$ cells mediates class switching and somatic hypermutation and finally leads to the replacement of primary IgM antibodies with mature IgG displaying high antigen affinity. High-affinity memory B cells and long-lived plasma cells, producing large amounts of antibodies, stay in secondary lymphoid organs or migrate to the bone marrow $[70,71]$.

The generation of carbohydrate-specific antibodies may in part follow the classical antigen presentation pathway and T-cell-dependent activation. Glycopeptides can be presented via MHC-II like standard peptide antigens. The carbohydrate moiety can be recognized by glycan-specific $\mathrm{B}$ cells, while $\mathrm{T}$ cells specifically recognizing the same glycopeptidic antigens provide the necessary co-stimulatory activity ensuring antibody maturation [72]. Some zwitterionic polysaccharides devoid of peptidic components share the ability to be processed by MHC-II to activate T cells and B cells [73-76]. The best-studied zwitterionic carbohydrate antigens include the type 1 capsular polysaccharide from Streptococcus pneumoniae [74, 76, 77], the capsular polysaccharide A from Bacteroides fragilis [74, 77], and zwitterionic motifs in Staphylococcus aureus polysaccharides [78].

Some types of antigens can activate B cells without $\mathrm{T}$ cell help. T-cell-independent antigens of type 1 include heterogeneous bacterial components that function as polyclonal B-cell activators. Type 2 antigens comprise polymers with repetitive motifs, such as polysaccharides [79]. Due to their structure type 2 antigens can cross-link several B-cell receptors, thereby leading to cell activation. In many cases, 


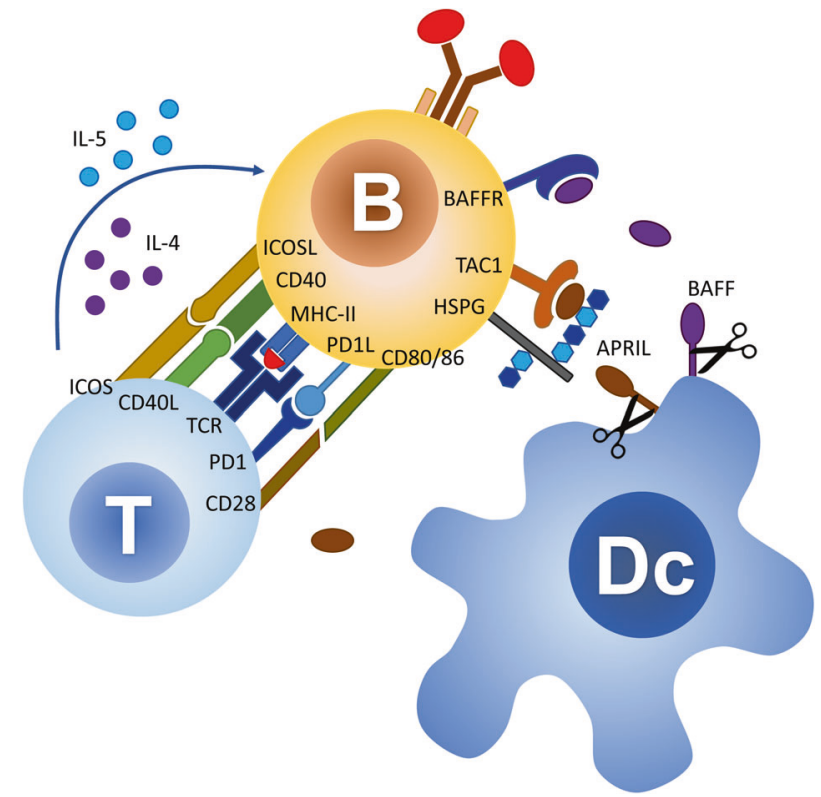

Fig. 3 T-cell-dependent and -independent activation of B-cells. $\mathrm{T}$ cells activate B-cells and promote antibody class switching through multiple interactions involving antigen-bound MHC-II with the T-cell receptor (TCR), and activation though the co-receptor systems CD40CD40L, ICOS-ICOSL, PD1/PD1L, and CD28-CD80/86. In the absence MHC-II presentation of antigens to $\mathrm{T}$ cells, B-cell activation and immunoglobulin class-switching can be mediated through binding to the activating proteins BAFF and APRIL secreted by myeloid cells, such as dendritic cells (Dc). APRIL binds to its receptor TAC1 on B cells after docking to heparan sulfate proteoglycans (HSPG).

T-cell-independent antigens trigger additional signals, such as binding to Toll-like receptors, to activate B cells [80]. This mechanism usually results in the generation of lowaffinity antibodies of the $\operatorname{IgM}$ and $\operatorname{IgG}$ class and in the inability to stimulate germinal centers and to induce immunological memory [81]. In mucosal tissue a T-cellindependent mechanism ensures an efficient B-cell activation, featuring immunoglobulin class-switch recombination. The pathway occurs mainly in the lamina propria and isolated lymphoid follicles. B-cell activation is enhanced by the TNF superfamily proteins BAFF [82] and APRIL [83], secreted by dendritic cells, which induce the expression of activation-induced cytidine deaminase (Fig. 3). B cells activated in this way undergo class-switch recombination, but not somatic hypermutation, as they do not re-enter the germinal centers [84]. The BAFF/APRIL-mediated pathway plays a major role in the emergence of carbohydrate-specific $\operatorname{IgG}$ and $\operatorname{IgA}$ arising after the microbial colonization of the gut [85].

Glycolipid antigens can be presented to T cells by MHClike proteins of the $\mathrm{CD} 1$ family that are mainly expressed on macrophages, dendritic cells, and B cells. MHC-I and CD1 are structurally related and share similar mechanisms of antigen presentation, with the exception that loading of glycolipid antigens is assisted by different lipid transfer proteins in endosomes [86]. In humans, the CD1 family consists of five isoforms, which are divided into three subgroups, CD1a-c, CD1d, and CD1e, binding different types of antigens. CD1d-presented glycolipids activate invariant natural killer $\mathrm{T}$ cells, which express an invariant alpha chain in their T-cell receptor, even though CD1dreactive cells with more variable $\mathrm{T}$-cell receptors have also been described [87]. CD1 isoforms are mainly associated with the presentation of glycolipids with short carbohydrate chains [88], which include microbial and self-lipids, lipopeptides, and glycolipid antigens, such as $\alpha$-Gal-ceramide, a glycosphingolipid found in marine sponges [89].

Although most carbohydrate-specific antibodies are of low affinity, recent works described high-affinity antibodies recognizing Klebsiella pneumoniae $\mathrm{O}$-antigens and related lipopolysaccharides (LPS) from other bacteria [68]. These antibodies underwent somatic mutations yielding strong antigen binding and lacked poly-reactivity. The authors suggested that the simultaneous uptake of glycan and protein antigens, both present in bacterial membranes, could explain how B cells recognizing O-antigens may indirectly receive assistance from $\mathrm{T}$ cells and go through affinity maturation. High levels of somatic hypermutation may result from many re-entries into germinal centers due to reactivity to different microbial species. This example underlines the importance to differentiate between unique antigen encounters, such as in nonrecurring infections, and repeated antigen exposure, as occurring in the context of commensal intestinal bacteria and environmental antigens.

\section{Induction of carbohydrate-specific antibodies through microbial exposure}

The permanent challenge of host immunity by the gut microbiota leads to high antibody titers against some carbohydrate antigens. In fact, the development of carbohydrate-specific antibodies coincides with the microbial colonization of the gut at birth. Before birth, IgG are transferred from the maternal circulation to the fetus crossing the placenta. Postnatally, additional maternal IgG and $\operatorname{IgA}$ are delivered through breast milk to the suckling infant [90]. Although the development and maturation of antibodies begins by the third trimester of gestation, neonatal antibodies are largely immature [91]. The development of functional $\operatorname{IgM}$ and $\operatorname{IgG}$ repertoires parallels the first contact with the extrauterine environment $[92,93]$, but take several years until completion of antibody maturation [94, 95]. Some carbohydrate-specific IgM have been reported in cord blood [96], although they remain marginal in the first weeks of life [97]. Within the first months of life, infants develop carbohydrate-specific antibodies such as ABO-specific IgM [98] and $\alpha$-Gal antibodies [29, 99]. At 
Fig. 4 Molecular mimicry between animal glycan epitopes and bacterial glycans. a Schematic structure of the Galili xenoantigen and Escherichia coli 086 O-antigen expressed on lipopolysaccharide (LPS). The conserved $\mathrm{Gal}(\alpha 1-3)$ Gal motif is highlighted in blue. b Structures of lipooligosaccharides (LOS) of Neisseria meningitidis and Haemophilus ducreyi including the lacto-N-neotetraose (LNnT) epitope found in human milk oligosaccharides and on glycosphingolipids. c Similarity between the Lewis Y epitope and the LPS of Helicobacter pylori M019. d Schematic structure of the ganglioside GM1 and the LOS epitope of Campylobacter jejuni.
A

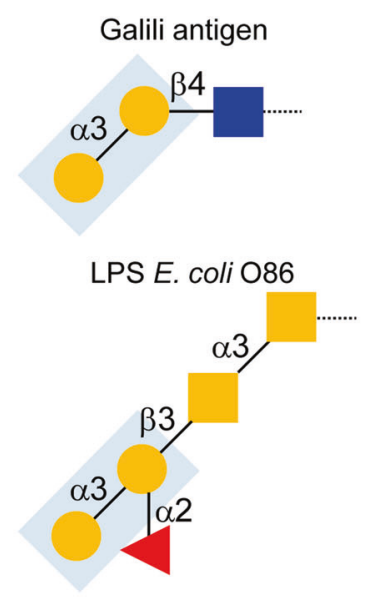

C

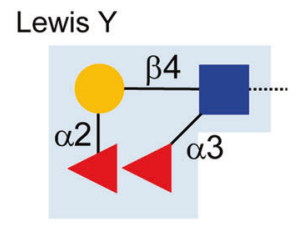

LPS Helicobacter pylori M019

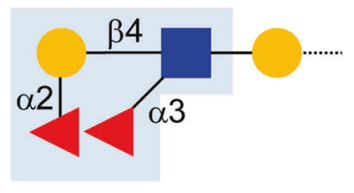

B Lacto-N-neotetraose (LNnT)

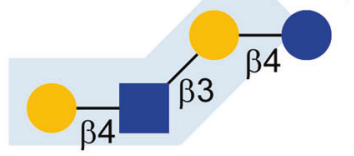

LOS Neisseria meningitidis L5

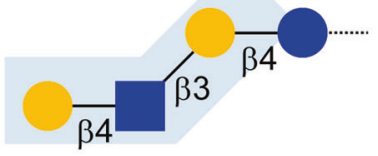

LOS Haemophilus ducreyi ITM2665, ITM4747 $\beta 3$

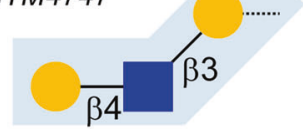

D GM1 ganglioside

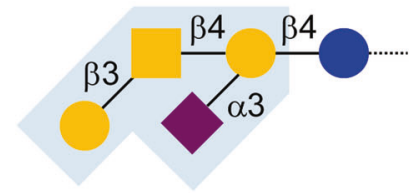

LOS Campylobacter jejuni CF 90-26

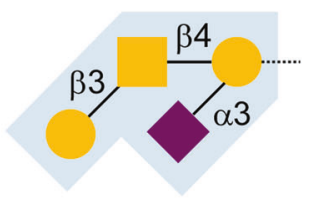

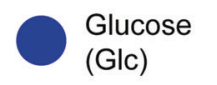

(Glc)

Galactose

(Gal)
$\mathrm{N}$-acetylglucosamine (GlcNAc)

$\mathrm{N}$-acetylgalactosamine (GalNAc)

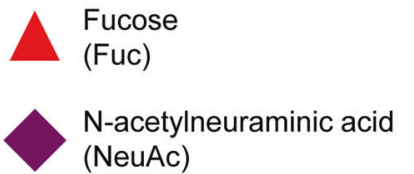

the age of 8 months, infants express $\mathrm{B} 1$ and $\mathrm{B} 2$ cell-derived $\mathrm{ABO}$ antibodies, thus indicating the maturation of specific antibodies to these antigens beyond natural antibodies [98]. The presence of B2 cell-derived ABO antibodies underlines the antibody maturation process driven by gut bacterial stimulation [100-102]. The same principle has been suggested for the production of $\alpha$-Gal-specific antibodies $[25,43]$. The $\alpha$-Gal epitope occurs on the surface of several Enterobacteriaceae, including Klebsiella species, Salmonella minnesota, and Escherichia coli O86:B7 [25, 103]. Colonization of mice deficient for the $\alpha 1-3$ Gal-transferase Ggta1 with E. coli O86:B7 resulted in the production of $\alpha$ Gal IgM [104]. Similarly, the ingestion of E. coli O86:B7 in humans triggered the production of antibodies to blood group B antigen, which includes an epitope related to $\alpha-\mathrm{Gal}$ [101] (Fig. 4a). A correlation between the composition of the gut microbiota and carbohydrate-specific antibodies was reported in Ggtal-null mice, in which changes in
Clostridiales, Bacteroidales, Lactobacillales, and Deferribacterales were related to changes in the levels and repertoires of carbohydrate-specific antibodies [105].

In addition to eliciting the production of antibodies, the gut microbiota largely contributes to the development of the mucosal immune system [106-108]. Carbohydrate-specific IgA secreted into the intestinal lumen bind directly to the microbiota [109, 110]. Beyond intestinal IgA, IgG targeting gut bacterial glycans, such as LPS, are also commonly found in blood serum [111-113]. These serum IgG recognize glycan epitopes of both commensal and pathogenic bacteria [66]. The titers of serum $\mathrm{IgG}$ recognizing gut bacteria increase after colonization of germ-free mice [114, 115]. These systemic antibodies elicited by the gut microbiota contribute to the protection of the host against infections with E. coli and Salmonella, as shown in a mouse model [116].

Gut microbes can stimulate the production of systemic antibodies through different mechanisms. Commensal gut 
bacteria can reach extra-intestinal sites by direct translocation and thereby induce systemic antibody responses [117]. Diseases, such as inflammatory bowel disease and diabetes, featuring increased permeability of the intestinal epithelium show elevated levels of circulating $\operatorname{IgG}$ to gut bacteria [118-121]. The loss of the barrier function and a subsequent translocation of bacteria into the system generally leads to anti-commensal IgG [122]. Transient or localized changes in intestinal permeability can also be triggered by gastrointestinal tract infections, drugs, toxins, malnutrition, or even psychological stress $[123,124]$. Some bacteria rely on virulent factors to penetrate the intestinal barrier and to reach the blood circulation [116]. Gut microbial antigens can also be sampled directly by dendritic cells extending their dendrites across the epithelium [125, 126]. Some microbial antigens can be captured by Peyer's patches and processed by underlying lymphoid cells during passage through the small intestine [127].

\section{Roles of carbohydrate-specific antibodies}

Intestinal carbohydrate-specific antibodies recognizing commensal bacteria help to control host-microbial homeostasis by mediating tolerance through the reduction of bacterial antigen expression and subsequent proinflammatory signaling [128]. Carbohydrate-specific antibodies targeting gut microbial glycans can cross-react with structurally similar antigens expressed on pathogens and thereby contribute to a broad protection against infections [44, 45]. $\alpha$-Gal antibodies originally directed toward gut bacteria, for example, confer a partial protection from the malaria agent Plasmodium falciparum. Circulating $\alpha$-Gal $\operatorname{IgM}$ and $\operatorname{IgG}$ bind to $\alpha$-Gal determinants on glycosylphosphatidylinositol-anchored proteins on the sporozoite form of $P$. falciparum. This mechanism explains why people with high $\alpha$-Gal IgM levels in malaria-endemic areas have a decreased risk of infection [104, 129]. In mice, $\alpha$-Gal antibody levels can be increased by oral administration of $E$. coli $\mathrm{O} 86: \mathrm{B} 7$, which expresses the $\alpha$-Gal epitope in the context of its LPS O-antigen [104] (Fig. 4a). Along this line, a gut microbiota with higher abundance of Enterobacteriaceae, including E. coli and Shigella, was associated with a reduced risk of $P$. falciparum infections in individuals from malaria-endemic regions [130]. The protection conferred by specific gut bacteria toward parasitic infections opens new perspectives for the incorporation of probiotics in new vaccination strategies toward malaria [131, 132].

Similar mechanisms of protection have been outlined for infections with Trypanosoma and Leishmania, as these parasites also express $\alpha$-Gal on their surface glycans [133]. Accordingly, Leishmania- or Trypanosoma-infected persons produce high levels of $\alpha$-Gal antibodies $[131,134,135]$. These $\alpha$-Gal antibodies can lyse trypomastigotes, the extracellular form of Trypanosoma cruzi found in the blood of infected people [136, 137]. Recently, vaccination with $\alpha$-Gal nanoparticles has been demonstrated to protect from Leishmania infection [138]. The protective effect of $\alpha$-Gal antibodies induced after infection or immunization with glycoconjugates presenting the $\alpha$-Gal epitope has been shown to be generally stronger than natural $\alpha$-Gal antibodies found in healthy individuals [139]. On the other hand, in some Gram-negative bacteria, binding of LPS by $\alpha$-Gal antibodies contributed to decreased complement activation through the alternative pathway, indicating that carbohydrate-specific antibodies may in some instances also contribute to the survival of pathogenic bacteria, acting so as facilitators of infectious diseases [140].

In contrast to the positive effects of $\alpha-G a l \operatorname{IgM}$ and $\operatorname{IgG}$ in the protection from infectious diseases, $\alpha$-Gal immunoglobulins of the $\operatorname{IgE}$ class have been associated with allergic reactions to red meat. Unclear cases of delayed anaphylactic reactions after the consumption of red meat have been associated with a history of tick bites in the affected patients [141, 142]. Further studies confirmed the induction of $\alpha$-Gal IgE consecutive to tick bites $[142,143]$. The $\alpha$-Gal epitope was determined in the saliva of the ticks [144], but the mechanisms leading to the generation of $\operatorname{IgE}$ toward that carbohydrate epitope remain unclear [143, 145]. These antibodies recognize the $\alpha$-Gal epitope present on glycoproteins and glycolipids of meat products from beef, pork or lamb, as demonstrated for the $\alpha$-Gal epitope in beef proteins, which was recognized by IgE of meat-allergy patients [146].

Interestingly, $\alpha$-Gal $\mathrm{IgE}$ antibodies are also responsible for triggering anaphylaxis to the anti-cancer drug Cetuximab, a monoclonal antibody containing $\alpha$-Gal epitopes on its glycan chains [147]. The presence of high levels of $\alpha$-Gal $\mathrm{IgE}$ in serum is now referred to as $\alpha$-Gal syndrome and, in theory, these antibodies can provoke allergic reactions to dairy products and gelatin containing food, as well as to pharmaceuticals, antivenoms and bioprosthetic heart valves [145]. Most of the studied cases, however, are restricted to immediate allergic reactions to Cetuximab and delayed reactions to red meat or immediate reactions to innards, such as pork kidney [148]. The delayed reaction to red meat ingestion is likely explained by the slow kinetics of digestion and absorption of lipid particles carrying $\alpha$-Gal-containing digestion products into the circulation $[149,150]$.

\section{Carbohydrate antigen mimicry}

Despite the vast structural differences between prokaryotic and eukaryotic glycoconjugates, specific carbohydrate 
structures are shared between phylogenetically distant organisms. Such structural similarities can be serendipitous or purposeful. The expression of ABO blood group antigens by gut microbes likely reflects a random selection process that is unrelated to the expression of $\mathrm{ABO}$ antigens on human cells. Some bacteria on the other hand rely on molecular mimicry [151] in order to evade host immunity or to exploit host immunity to facilitate infection [72, 152]. Pathogenic bacteria including Neisseria meningitidis, Neisseria gonorrhoeae, Haemophilus influenzae, and Haemophilus ducreyi express lipooligosaccharides (LOS) carrying epitopes similar to lactoneo-series glycosphingolipids [152-157] (Fig. 4b). N. gonorrhoeae, N. meningitidis and $H$. influenzae also express sialylated LOS structures [158-161]. In addition to mimicking LOS, $N$. meningitidis synthesize a protective polysaccharide capsule of polysialic acid. Whereas group $\mathrm{C}$ meningococci produces a polymer of $\alpha 2-9$-linked sialic acid that is highly immunogenic, the capsule of group B meningococci is built of $\alpha 2-8$-linked sialic acid [72], which mimics host polysialic acid [162]. The hyaluronic acid capsule of group A streptococci is another example of antigen mimicry, which contributes to the virulence of the pathogen [163, 164] while imitating hyaluronic acid, an essential component of the human extracellular matrix [165]. Several gut bacteria express carbohydrate epitopes similar or identical to human glycans. Many strains of Helicobacter pylori present fucosylated Oantigens structures similar to fucosylated Lewis X or Lewis Y blood group antigens [152, 166] (Fig. 4c). Further examples of mammalian glycoprotein epitopes in bacterial O-polysaccharides are found in different E. coli serotypes and include $\mathrm{T}$ antigen, sialyl-T antigen and type 1 and 2 chains [167].

The expression of mimicking carbohydrate antigens by gut bacteria often relies on the salvage of monosaccharides derived from host glycoconjugates. $H$. influenzae, for instance, uses host-derived sialic acid to assemble its LPS [168]. N. gonorrhoeae also incorporates host-derived sialic acid into its LOS [160]. Fuc is another host-derived monosaccharide frequently internalized by gut bacteria. Bacteroides thetaiotaomicron and other members of the genus Bacteroides express fucosidase enzymes and Fuc transport systems enabling the internalization and utilization of the monosaccharide [169]. Besides catabolism for energy production, Fuc can be converted to the activated form GDP-Fuc by the enzyme L-fucokinase/GDP-Fuc pyrophosphorylase [170], which leads to the incorporation into bacterial capsular polysaccharides or glycoproteins [72]. While the production of mimicking carbohydrate antigens may contribute to the survival of commensal or pathogenic bacteria by enabling evasion from the host immune system, the recognition of antigens similar to endogenous glycans may lead to the generation of carbohydrate-specific antibodies triggering autoimmune reactions by crossreacting with host glycoconjugates.

\section{Autoimmunity}

Molecular mimicry has been shown to contribute to the emergence of autoimmune diseases, such as Guillain-Barré syndrome and multiple sclerosis. Guillain-Barré syndrome represents a typical example of autoimmune disorder that can be caused by cross-reacting antibodies emerging after a bacterial infection [171]. Guillain-Barré syndrome is a neuropathy of the peripheral nervous system, in which neurons are damaged through an immune reaction involving antibodies reacting toward surface gangliosides. The disease is a major cause of acute flaccid paralysis in humans since the elimination of poliomyelitis [172-174]. Several bacterial and viral infections have been shown to contribute to the development of Guillain-Barré syndrome. Campylobacter jejuni, a bacterium causing acute enteritis [175], is the pathogen most commonly associated with Guillain-Barré syndrome [176]. Antibodies directed to $C$. jejuni surface antigens cross-react with gangliosides expressed on peripheral nerves, thereby contributing to demethylation and axonal damage [177-179]. C. jejuni expresses sialylated LOS structures, which strongly resemble gangliosides, such as GM1 (Fig. 4d). Suspected molecular mimicry in the development of Guillain-Barré syndrome was further confirmed by studies showing anti-ganglioside antibodies in the serum of patients with Guillain-Barré syndrome [180, 181]. Evidence from animal experiments further demonstrated that rabbits immunized with ganglioside-mimicking $C$. jejuni LOS developed high titers of LOS antibodies crossreactive with host gangliosides [182].

Multiple sclerosis is another autoimmune disease in which autoantibodies specific for carbohydrate epitopes have been identified. Autoantibodies targeting myelin proteins initiate the injury of white and gray matter of the central nervous system, thereby leading to progressive muscle weakness, paresthesia, vision changes and cognitive decline [183, 184]. Increased levels of antibodies targeting the gangliosides GM1, GM2, and G7 have been reported in multiple sclerosis patients [185, 186]. Additional autoreactive carbohydrate-specific antibodies have been identified over the past years, such as antibodies reacting with Glc ( $\alpha 1-4)$ Glc [10, 187], galactocerebroside [188], and sulfated carbohydrates [189]. The involvement of possible infectious agents in the development of these autoreactive antibodies remains unclear.

Increased titers of carbohydrate-specific antibodies also occur in inflammatory bowel disease, which comprises Crohn's disease and ulcerative colitis. These antibodies recognize oligosaccharides that are frequently found on the 
surface of gut microbes, such as laminaribioside, laminarin, mannobioside, chitobioside, and chitin [190-193]. In our own studies, we observed an increased antibody response to carbohydrates in blood serum of patients with Crohn's disease compared with healthy controls, which was mainly reflected by a higher antibody reactivity to fucosylated oligosaccharides and could be linked to increased antibody recognition of intestinal Bacteroides species [194]. Given the association between intestinal dysbiosis and altered antibacterial antibodies, the question arises whether these antibodies targeting bacterial antigens contribute to the etiology of inflammatory bowel disease. Despite the large number of studies outlining alterations of the intestinal microbiota and increase of carbohydrate-specific antibodies in inflammatory bowel disease, a direct connection between these antibodies and an exacerbation of the inflammatory response observed in inflammatory bowel disease is still to establish. Beyond the examples addressed here above, increased levels of carbohydrate-specific antibodies have been also reported in other autoimmune diseases, including systemic lupus erythematosus, diabetes type 1 and poststreptococcal heart disease [186, 195-198].

\section{Analytical tools}

The investigation of carbohydrate-protein interactions significantly lags behind similar studies on other macromolecule interactions because of the challenges associated with the purification and synthesis of glycans. Considering the broad structural diversity of glycoconjugates, techniques enabling the parallel and quantitative analysis of a wide range of carbohydrate structures are likely to yield the most reliable information about the specificity and affinity of antibodies recognizing glycan antigens. Accordingly, large-scale glycan arrays have turned out as being valuable resources for the quantitative analysis of carbohydrate-protein interactions [199].

While arrays displaying nucleic acids [200] have been applied widely for several decades, the first glycan arrays [201-203] emerged in the early 2000s. Glycan arrays mainly consist of purified or chemically synthesized glycans, which are immobilized on glass slides by either direct adsorption of glycans to nitrocellulose surfaces or different methods of chemical linkage. Using glycans with attached chemical linkers and slides covered with matching functional groups, covalent immobilization chemistry overcomes the limitations of adsorption, which include varying immobilization efficiencies and unspecific binding. Chemical immobilization is mostly performed by reaction of amine-functionalized glycans with $\mathrm{N}$-hydroxysuccinimide esters, thio-functionalized glycans with maleimide groups and amine- or thio-functionalized glycans with epoxy groups. In addition, glycans without a linker can be coupled covalently via the free reducing end to surfaces with hydrazides or oxyamines [204, 205]. One type of arrays displays known structures, whereas shotgun arrays are made up of glycans, isolated from natural sources with yet undefined structures. Besides the structural analysis of single unknown glycans by mass spectrometry and NMR spectroscopy, glycans on shotgun arrays can be analyzed by glycan-binding proteins directly on the array [206]. Glycan arrays with defined glycan structures have been applied to characterize the binding specificity of glycan-binding proteins, where previously reported specificities of several plant lectins, human, bacterial, and viral glycan-binding proteins could be confirmed [207]. The same study detected a variety of carbohydrate-specific antibodies in human serum and suggested the use of glycan arrays in diagnosis [207]. Indeed, glycan arrays are also used as diagnostic tools to detect carbohydrate-specific antibodies targeting glycan structures specific for bacterial or viral antigens or to glycan cancer markers. An advantage of the detection of immobilized well-characterized polysaccharides by human serum antibodies over the detection with crude bacterial lysates is the avoidance of false-positive diagnoses [208]. The specific detection of antibodies to capsular polysaccharides of Burkholderia mallei in the serum of a human glanders patient compared with the absence of these antibodies in the pre-infection serum of the same person was demonstrated [208]. Further, microarray analysis allowed for the differentiation of different types of Salmonella infections. Testing sera from patients with verified types of salmonellosis on a microarray with $\mathrm{O}$-antigenic oligosaccharides specific for Salmonella enterica serovar Paratyphi, Typhimurium, or Enteriditis, antibodies were correctly detected [209].

The application of glycan arrays can provide valuable information complementary to established genetic markers, for example when establishing new biomarkers in different types of cancer. Based on glycan arrays, 24 glycans could be identified that significantly discriminated between malignant tumors and healthy controls in the context of ovarian cancer [210]. Another study showed the association between serum antibody levels to specific glycans in Hodgkin's lymphoma [211]. Glycan arrays are also used in the development of glycoconjugate vaccines, by enabling the quick screening of a broad panel of potential glycan structures as targets for serum antibodies from infected people [212]. For example, the analysis of stool and serum samples from Clostridium difficile patients on microarrays containing oligosaccharide epitopes of the $C$. difficile cell wall polysaccharides PS-I and PS-II confirmed novel vaccine candidates [213]. Glycan arrays are powerful resources when assessing bacteria or viruses binding to host carbohydrate structures, such as interactions of the influenza virus to host receptors [214-217]. Further, arrays consisting of immobilized antibodies or lectins have been developed to analyze 
carbohydrate-binding properties [218]. Additional tools to analyze carbohydrate-specific antibodies in a similar fashion include classical methods, such as ELISA [219, 220], but also innovative approaches, including multiplex suspension arrays [221] or cell-based glycan arrays [222].

Another method to study unknown glycans structures is the analysis of enzymes required for glycan synthesis, such as glycosyltransferases or transport proteins for glycan precursors. Given that glycans, in contrast to proteins, are not encoded by a genomic template, they cannot be directly identified at the genomic level. The identification of genes encoding glycosyltransferases or transport proteins for glycan precursors yields information to predict glycan assembly. Recently, gene analysis identified thousands of glycan enzymes in Bacteroides species [223]. In bacterial genomes, glycosylation genes are often clustered in glycosylation loci, which can be identified by searching for conserved genes. Identified genes can be expressed recombinantly to verify their function and to analyze resulting glycan structures. Additional genetical engineering of commensal bacteria using CRISPR interference to manipulate gene expression was introduced recently [224]. Approaches with $\mathrm{CHO}$ cells or engineered phage display for glycan arrays combine the genomic possibilities with classical glycan array analysis to allow fast and cost-effective high-throughput testing [222, 225]. Cell-based glycan arrays enable testing of glycan binding directly on the surface of CHO cells by flow cytometry. Using recombinant glycosyltransferases, sialic acid, and Fuc, the small number of different glycan structures naturally occurring on $\mathrm{CHO}$ cells can be transformed into a diverse glycan repertoire with distinct carbohydrate epitopes. The utility of cell-based glycan arrays was demonstrated by the identification of high-affinity ligands linked to osteoclast differentiation when testing osteoprogenitor cells with cells expressing Siglec-15 ligands [222]. To overcome the challenges of chemical synthesis or time-consuming isolation of glycans, glycoarrays with engineered $E$. coli-derived phages displaying diverse surface glycan epitopes have been developed. In contrast to cell-based glycan arrays, where cells are detected by flow cytometry, glycophages can be immobilized on glass slides, enabling high-throughput detection of glycan interactions in a classical array format [225].

\section{Concluding remarks}

Carbohydrate-specific antibodies are often referred to as natural antibodies without underlying specific maturation process. This simplistic view does not account for the large number of carbohydrate-specific antibodies emerging in response to the exposure to the gut microbiota starting at birth, as demonstrated for the high titers of ABO- and $\alpha$ -
Gal-specific antibodies. The presence of systemic bacterially induced carbohydrate-specific antibodies contributes to the protection from pathogens but can in cases of antigenic mimicry also account for the development of autoimmune diseases. The functions of carbohydrate-specific antibodies largely underline their significance in human health and disease.

Acknowledgements This work was supported by the Swiss National Foundation grant 314730_172880 to TH. Open Access funding provided by Universität Zürich.

\section{Compliance with ethical standards}

Conflict of interest The authors declare that they have no conflict of interest.

Publisher's note Springer Nature remains neutral with regard to jurisdictional claims in published maps and institutional affiliations.

Open Access This article is licensed under a Creative Commons Attribution 4.0 International License, which permits use, sharing, adaptation, distribution and reproduction in any medium or format, as long as you give appropriate credit to the original author(s) and the source, provide a link to the Creative Commons license, and indicate if changes were made. The images or other third party material in this article are included in the article's Creative Commons license, unless indicated otherwise in a credit line to the material. If material is not included in the article's Creative Commons license and your intended use is not permitted by statutory regulation or exceeds the permitted use, you will need to obtain permission directly from the copyright holder. To view a copy of this license, visit http://creativecommons. org/licenses/by/4.0/.

\section{References}

1. Sterner E, Flanagan N, Gildersleeve JC. Perspectives on antiglycan antibodies gleaned from development of a community resource database. ACS Chem Biol. 2016;11:1773-83.

2. Moremen KW, Tiemeyer M, Nairn AV. Vertebrate protein glycosylation: diversity, synthesis and function. Nat Rev Mol Cell Biol. 2012;13:448-62.

3. Holden HM, Cook PaulD, Thoden JB. Biosynthetic enzymes of unusual microbial sugars. Curr Opin Struct Biol. 2010;20: 543-50.

4. Herget S, Toukach PV, Ranzinger R, Hull WE, Knirel YA, von der Lieth C. Statistical analysis of the Bacterial Carbohydrate Structure Data Base (BCSDB): characteristics and diversity of bacterial carbohydrates in comparison with mammalian glycans. BMC Struct Biol. 2008;8:35.

5. Freeze HH, Hart GW, Schnaar RL Glycosylation Precursors. In: Varki ACR, Esko JD, et al., editor Essentials of glycobiology. 3rd ed., vol. Chapter 5. Cold Spring Harbor, NY: Cold Spring Harbor Laboratory Press; 2017.

6. Varki A. Loss of N-glycolylneuraminic acid in humans: mechanisms, consequences, and implications for hominid evolution. Yearb Phys Anthropol.2001;33(Suppl):54-69.

7. Chiani P, Bromuro C, Cassone A, Torosantucci A. Anti-betaglucan antibodies in ealthy human subjects. Vaccine. 2009;27: 513-9. 
8. Tytgat HL, Lebeer S. The sweet tooth of bacteria: common themes in bacterial glycoconjugates. Microbiol Mol Biol Rev. 2014;78:372-417.

9. Bovin N, Obukhova P, Shilova N, Rapoport E, Popova I, Navakouski M, et al. Repertoire of human natural anti-glycan immunoglobulins. Do we have auto-antibodies? Biochim Biophys Acta. 2012;1820:1373-82.

10. Dotan N, Altstock RT, Schwarz M, Dukler A. Anti-glycan antibodies as biomarkers for diagnosis and prognosis. Lupus. 2006;15:442-50.

11. Huflejt ME, Vuskovic M, Vasiliu D, Xu H, Obukhova P, Shilova $\mathrm{N}$, et al. Anti-carbohydrate antibodies of normal sera: findings, surprises and challenges. Mol Immunol. 2009;46:3037-49.

12. McMorrow IM, Comrack CA, Sachs DH, DerSimonian H. Heterogeneity of human anti-pig natural antibodies crossreactive with the $\mathrm{Gal}(\mathrm{a} 1,3)$ Galactose epitope. Transplantation. 1997;64:501-10.

13. Lacroix-Desmazes S, Monthon L, Coutinho A, Kazatchkine MD. Analysis of the natural human IgG antibody repertoire: life-long stability of reactivities towards self antigens contrasts with agedependent diversification of reactivities against bacterial antigens. Eur J Immunol. 1995;25:2598-604.

14. Oyelaran O, McShane LM, Dodd L, Gildersleeve JC. Profiling human serum antibodies with a carbohydrate antigen microarray. J Proteome Res. 2009;8:4301-10.

15. Mistou MY, Sutcliffe IC, van Sorge NM. Bacterial glycobiology: rhamnose-containing cell wall polysaccharides in Gram-positive bacteria. FEMS Microbiol Rev. 2016;40:464-79.

16. Giraud M, Naismith JH. The rhamnose pathway. Curr Opin Struct Biol. 2000;10:687-96.

17. Muchmore EA, Diaz S, Varki A. A structural difference between the cell surfaces of humans and the great apes. Am J Phys Anthropol. 1998;107:187-98.

18. Zhu A, Hurst R. Anti-N-glycolylneuraminic acid antibodies identified in healthy human serum. Xenotransplantation. 2002;9: 376-81.

19. Padler-Karavani V, Varki A. Potential impact of the non-human sialic acid $\mathrm{N}$-glycolylneuraminic acid on transplant rejection risk. Xenotransplantation. 2011;18:1-5.

20. Galili U. Natural anti-carbohydrate antibodies contributing to evolutionary survival of primates in viral epidemics? Glycobiology. 2016;26:1140-50.

21. Padler-Karavani V, Tremoulet AH, Yu H, Chen X, Burns JC, Varki A. A simple method for assessment of human anti-Neu5Gc antibodies applied to Kawasaki disease. PLoS ONE. 2013;8: e58443.

22. Galili U, Macher BA, Buehler J, Shohet SB. Human natural antialpha-galactosyl IgG. II. The specific recognition of alpha (1>3)-linked galactose residues. J Exp Med. 1985;162:573-82.

23. Galili U. A unique natural human IgG antibody with anti-alphagalactosyl specificity. J Exp Med. 1984;160:1519-31.

24. Galili U, Anaraki F, Thall A, Hill-Black C, Radic M. One percent of human circulating B lymphocytes are capable of producing the natural anti-gal antibody. Blood. 1993;82:2485-93.

25. Galili U, Mandrell RE, Hamadeh RM, Shohet SB, McLeod Griffiss J. Interaction between human natural anti-a-galactosyl immunoglobulin $\mathrm{G}$ and bacteria of the human flora. Infect Immun. 1988;56:1730-7.

26. Galili U, Swanson K. Gene sequences suggest inactivation of alpha-1,3-galactosyltransferase in catarrhines after the divergence of apes from monkeys. Proc Natl Acad Sci USA. 1991;88:7401-4.

27. Cooper DKC, Good AH, Koren E, Oriol R, Malcolm AJ, Ippolito RM, et al. Identification of a-galactosyl and other carbohydrate epitopes that are bound by human anti-pig antibodies: relevance to discordant xenografting in man. Transpl Immunol. 1993;1:198-205.

28. Joziasse DH, Oriol R. Xenotransplantation: the importance of the Gala1-3Gal epitope in hyperacute vascular rejection. Biochim Biophys Acta. 1999;1455:403-18.

29. Hamanova M, Chmelikova M, Nentwich I, Thon V, Lokaj J. Anti-Gal IgM, IgA and IgG natural antibodies in childhood. Immunol Lett. 2015;164:40-3.

30. Hakomori S. Glycolipids of tumor cell membrane. Adv Cancer Res. 1973;18:265-315.

31. Bovin N, Obukhova P, Shilova N, Rapoport E, Popova I, Navakouski M, et al. Repertoire of human natural anti-glycan immunoglobulins. Do we have auto-antibodies? Biochim Biophys Acta. 2012;1820:1373-82.

32. Bello-Gil D, Khasbiullina N, Shilova N, Bovin N, Manez R. Repertoire of BALB/c mice natural anti-carbohydrate antibodies: mice vs. humans difference, and otherness of individual animals. Front Immunol. 2017;8:1449.

33. Yamamoto F, Clausen H, White T, Marken J, Hakomori S. Molecular genetic basis of the histo-blood group ABO system. Nature. 1990;17:6272.

34. Soejima M, Koda Y. Molecular mechanisms of Lewis antigen expression. Leg Med. 2005;7:266-9.

35. Henry S, Oriol R, Samuelsson B. Lewis histo-blood group system and associated secretory phenotypes. Vox Sanguinis. 1995;69:166-82.

36. Spitalnik PF, Spitalnik SL. The P blood group system: biochemical, serological, and clinical aspects. Transfus Med Rev. 1995;9:110-22.

37. Steffensen R, Carlier K, Wiels J, Levery SB, Stroud M, Cedergren $\mathrm{B}$, et al. Cloning and expression of the histo-blood group Pk UDP-galactose: Galb1-4Glcb1-Cera1,4-galactosyltransferase. J Biol Chem. 2000;275:16723-9.

38. Thuresson B, Westman JS, Olsson ML. Identification of a novel A4GALT exon reveals the genetic basis of the P1/P2 histo-blood groups. Blood. 2011;117:678-87.

39. Hellberg A, Poole J, Olsson ML. Molecular basis of the globoside-deficient Pk blood group phenotype. J Biol Chem. 2002;277:29455-9.

40. Holodick NE, Rodriguez-Zhurbenko N, Hernandez AM. Defining natural antibodies. Front Immunol. 2017;8:872.

41. Baumgarth N, Tung JW, Herzenberg LA. Inherent specificities in natural antibodies: a key to immune defense against pathogen invasion. Semin Immunopathol. 2005;26:347-62.

42. Houghteling PD, Walker WA. Why is initial bacterial colonization of the intestine important to infants' and children's health? J Pediatr Gastroenterol Nutr. 2015;60:294-307.

43. Macher BA, Galili U. The Gal $\alpha 1,3 \mathrm{Gal} \beta 1,4 \mathrm{GlcNAc-R}(\alpha-\mathrm{Gal})$ epitope: a carbohydrate of unique evolution and clinical relevance. Biochim Biophys Acta. 2008;1780:75-88.

44. Zhou Z, Zhang Y, Hu Y, Wahl LM, Cisar JO, Notkins AL. The broad antibacterial activity of the natural antibody repertoire is due to polyreactive antibodies. Cell Host Microbe. 2007;1:51-61.

45. Puga I, Cerutti A. Protection by natural IgG: a sweet partnership with soluble lectins does the trick! The. EMBO J. 2013;32: 2897-9.

46. Coutinho A, Kazatchkine MD, Avrameas S. Natural autoantibodies. Curr Opin Immunol. 1995;7:812-8.

47. Ikematsu H, Schettino E, Casali P. Structure of the VH-D-JH segments of human natural polyreactive $\operatorname{IgM}$ and $\mathrm{IgG}$ antibodies. Use of germline or somatically mutated forms of commonly expressed VH genes. Ann N Y Acad Sci. 1995;764:362-9.

48. Mouthon L, Haury M, Lacroix-Desmazes S, Barreau C, Coutinho A, Kazatchkine MD. Analysis of the normal human IgG antibody repertoire. Evidence that IgG autoantibodies of healthy 
adults recognize a limited and conserved set of protein antigens in homologous tissue. J Immunol. 1995;154:5769-78.

49. Ochsenbein AF, Zinkernagel RM. Natural antibodies and complement link innate and acquired immunity. Immunol Today. 2000;21:624-30.

50. Toellner K, Jenkinson WE, Taylor DR, Khan M, Sze DM, Sansom DM, et al. Low-level hypermutation in $\mathrm{T}$ cell-independent germinal centers compared with high mutation rates associated with $\mathrm{T}$ cell-dependent germinal centers. J Exp Med. 2002;195:383-9.

51. Reynaud C, Garcia C, Hein WR, Weill J. Hypermutation generating the sheep immunoglobulin repertoire is an antigenindependent process. Cell. 1995;80:115-25.

52. Sindhava VJ, Bondada S. Multiple regulatory mechanisms control B-1 B cell activation. Front Immunol. 2012;3:372.

53. Griffin DO, Holodick NE, Rothstein TL. Human B1 cells in umbilical cord and adult peripheral blood express the novel phenotype CD20+ CD27+ CD43+ CD70. J Exp Med. 2011;208:67-80.

54. Kantor AB, Herzenberg LA. Origin of murine B cell lineages. Annu Rev Immunol. 1993;11:501-38.

55. Hardy RR, Hayakawa K. B cell development pathways. Annu Rev Immunol. 2001;19:595-621.

56. Kantor AB, Merrill CE, Herzenberg LA, Hillson JL. An unbiased analysis of $\mathrm{V}(\mathrm{H})-\mathrm{D}-\mathrm{J}(\mathrm{H})$ sequences from B-1a, B-1b, and conventional B cells. J Immunol. 1997;158:1175-86.

57. Panda S, Zhang J, Tan NS, Ho B, Ding JL. Natural IgG antibodies provide innate protection against ficolin-opsonized bacteria. The. EMBO J. 2013;32:2905-19.

58. Tornberg U, Holmberg DB-1a. B-1b and B-2 B cells display unique VHDJH repertoires formed at different stages of ontogeny and under different selection pressures. EMBO J. 1995;14:1680-9.

59. Holodick NE, Vizconde T, Hopkins TJ, Rothstein TL. Agerelated decline in natural $\mathrm{IgM}$ function: diversification and selection of the B-1a cell pool with age. J Immunol. 2016;196:4348-57.

60. Yang Y, Wang C, Yang Q, Kantor AB, Chu H, Ghosn EEB, et al. Distinct mechanisms define murine B cell lineage immunoglobulin heavy chain (IgH) repertoires. eLife. 2015;4:e09083.

61. Hooijkaas H, Benner R, Pleasants JR, Wostmann BS. Isotypes and specificities of immunoglobulins produced by germ-free mice fed chemically defined ultrafiltered "antigen-free" diet. Eur J Immunol. 1984;14:1127-30.

62. MacKenzie CR, Hirama T, Deng S, Bundle DR, Narang SA, Young NM. Analysis by surface plasmon resonance of the influence of valence on the ligand binding affinity and kinetics of an anti-carbohydrate antibody. The. J Biol Chem. 1996;271:1527-33.

63. Barrett DJ, Ayoub EM. IgG2 subclass restriction of antibody to pneumococcal polysaccharides. Clin exp Immunol 1986;63: 127-34.

64. Hammarström L, Smith CIE. IgG2 deficiency in a healthy blood donor. Concomitant lack of IgG2, IgA and IgE immunoglobulins and specific anti-carbohydrate antibodies. Clin Exp Immunol. 1983;51:600-4.

65. Yount WJ, Dorner MM, Kunkel HG, Kabat EA. Studies on human antibodies VI. Selective variations in subgroup composition and genetic markers. J Exp Med. 1968;127:633-46.

66. Schneider C, Smith DF, Cummings RD, Boligan KF, Hamilton $\mathrm{RG}$, Bochner BS, et al. The human IgG anti-carbohydrate repertoire exhibits a universal architecture and contains specificity for microbial attachment sites. Sci Transl Med. 2015;7:269ra1.

67. von Gunten S, Smith DF, Cummings RD, Riedel S, Miescher S, Schaub A, et al. Intravenous immunoglobulin contains a broad repertoire of anticarbohydrate antibodies that is not restricted to the IgG2 subclass. The. J allergy Clin Immunol. 2009;123: 1268-76.

68. Rollenske T, Szijarto V, Lukasiewicz J, Guachalla LM, Stojkovic $\mathrm{K}$, Hartl $\mathrm{K}$, et al. Cross-specificity of protective human antibodies against Klebsiella pneumoniae LPS O-antigen. Nat Immunol. 2018;19:617-24.

69. Mantegazza AR, Magalhaes JG, Amigorena S, Marks MS. Presentation of phagocytosed antigens by MHC class I and II. Traffic. 2013;14:135-52.

70. Blum JS, Wearsch PA, Cresswell P. Pathways of antigen processing. Annu Rev Immunol. 2013;31:443-73.

71. Murphy KM, Weaver C. Die humorale Immunantwort. In: Murphy KM, Weaver C, editors. Janeway Immunologie, vol. Kapitel 10. Berlin, Heidelberg: Springer Spektrum; 2018, pp 517-80.

72. Comstock LE, Kasper DL. Bacterial glycans: key mediators of diverse host immune responses. Cell. 2006;126:847-50.

73. Cobb BA, Wang Q, Tzianabos AO, Kasper DL. Polysaccharide processing and presentation by the MHCII pathway. Cell. 2004;117:677-87.

74. Kalka-Moll WM, Tzianabos AO, Bryant PW, Niemeyer M, Ploegh HL, Kasper DL. Zwitterionic polysaccharides stimulate $\mathrm{T}$ cells by MHC class II-dependent interactions. J Immunol. 2002;169:6149-53.

75. Avci FY, Kasper DL. How bacterial carbohydrates influence the adaptive immune system. Annu Rev Immunol. 2010;28:107-30.

76. Velez CD, Lewis CJ, Kasper DL, Cobb BA. Type I Streptococcus pneumoniae carbohydrate utilizes a nitric oxide and MHC II-dependent pathway for antigen presentation. Immunology. 2009;127:73-82.

77. Tzianabos AO, Finberg RW, Wang Y, Chan M, Onderdonk AB, Jennings $\mathrm{HJ}$, et al. T cells activated by zwitterionic molecules prevent abscesses induced by pathogenic bacteria. J Biol Chem. 2000;275:6733-40.

78. Tzianabos AO, Wang JY, Lee JC. Structural rationale for the modulation of abscess formation by Staphylococcus aureus capsular polysaccharides. Proc Natl Acad Sci USA. 2001;98:9365-70.

79. Stein KE. Thymus-independent and thymus-depdent responses to polysaccharide antigens. J Infect Dis. 1992;165:S49-52.

80. Bonilla FA, Oettgen HC. Adaptive immunity. J Allergy Clin Immunol. 2010;125(Suppl 2):S33-40.

81. Mond JJ, Lees A, Snapper CM. T cell-independent antigens type II. Annu Rev Immunol. 1995;13:655-92.

82. Moore PA, Belvedere O, Orr A, Pieri K, LaFleur DW, Feng P, et al. BLyS: member of the tumor necrosis factor family and B lymphocyte stimulator. Science. 1999;285:260-3.

83. Hahne M, Kataoka T, Schröter M, Hofmann K, Irmler M, Bodmer J, et al. APRIL, a new ligand of the tumor necrosis factor family, stimulates tumor cell growth. J Exp Med. 1998;188:1185-90.

84. Honda K, Littman DR. The microbiota in adaptive immune homeostasis and disease. Nature. 2016;535:75-84.

85. Kim M, Kim CH. Regulation of humoral immunity by gut microbial products. Gut Microbes. 2017;8:392-9.

86. Teyton L. Role of lipid transfer proteins in loading CD1 Antigen Presenting Molecules. J Lipid Res. 2018;59:1367-73.

87. Zajonc DM, Kronenberg M. CD1 mediated T cell recognition of glycolipids. Curr Opin Struct Biol. 2007;17:521-9.

88. Young DC, Moody DB. T-cell recognition of glycolipids presented by CD1 proteins. Glycobiology. 2006;16:103R-12R.

89. Brigl M, Brenner MB. CD1: antigen presentation and $\mathrm{T}$ cell function. Annu Rev Immunol. 2004;22:817-90.

90. Van de Perre P. Transfer of antibody via mother's milk. Vaccine. 2003;21:3374-6. 
91. Schroeder HW, Zhang L, Philips JB. Slow, programmed maturation of the immunoglobulin HCDR3 repertoire during the third trimester of fetal life. Blood. 2001;98:2745-51.

92. Zola H. The development of antibody responses in the infant. Immunol cell Biol. 1997;75:587-90.

93. Nguyen QN, Himes JE, Martinez DR, Permar SR. The impact of the gut microbiota on humoral immunity to pathogens and vaccination in early infancy. PLoS Pathog. 2016;12:e1005997.

94. Martin R, Nauta AJ, Ben Amor K, Knippels LM, Knol J, Garssen J. Early life: gut microbiota and immune development in infancy. Beneficial Microbes. 2010;1:367-82.

95. Simon AK, Hollander GA, McMichael A. Evolution of the immune system in humans from infancy to old age. Proc R Soc B: Biol Sci. 2015;282:20143085.

96. Xia L, GildersleeveI JC. Anti-glycan IgM repertoires in newborn human cord blood. PLoS ONE. 2019;14:e0218575.

97. New JS, King RG, Kearney JF. Manipulation of the glycanspecific natural antibody repertoire for immunotherapy. Immunol Rev. 2016;270:32-50.

98. Wuttke NJ, Macardle PJ, Zola H. Blood group antibodies are made by CD5+ and by CD5- B cells. Immunol Cell Biol. 1997;75:478-83.

99. Doenz U, Nydegger UE, Kueng A, Carrel T, Mohacsi P. Antigalalpha1-3Gal IgM/IgG antibody levels in infants: do they have a clinical relevance in pediatric xenotransplantation?. J Heart Lung Transplant. 2000;19:1108-13.

100. Springer GF, Williamson P, Brandes WC. Blood group activity of gram-negative bacteria. J Exp Med. 1961;113:1077-93.

101. Springer GF, Horton RE. Blood group isoantibody stimulation in man by feeding blood group-active bacteria. J Clin Investig. 1969;48:1280-91.

102. Kay LA. Cellular basis of immune response to antigens of the AB0 blood group system. Lancet. 1984;2:1369-71.

103. Guo H, Yi W, Shao J, Lu Y, Zhang W, Song J, et al. Molecular analysis of the O-antigen gene cluster of Escherichia coli O86:B7 and characterization of the chain length determinant gene (wzz). Appl Environ Microbiol. 2005;71:7995-8001.

104. Yilmaz B, Portugal S, Tran TM, Gozzelino R, Ramos S, Gomes $\mathrm{J}$, et al. Gut microbiota elicits a protective immune response against malaria transmission. Cell. 2014;159:1277-89.

105. Bello-Gil D, Audebert C, Olivera-Ardid S, Perez-Cruz M, Even G, Khasbiullina N, et al. The formation of glycan-specific natural antibodies repertoire in GalT-KO mice is determined by gut microbiota. Front Immunol. 2019;10:342

106. Kamada N, Chen GY, Inohara N, Nunez G. Control of pathogens and pathobionts by the gut microbiota. Nat Immunol. 2013;14:685-90.

107. Macpherson AJ, Geuking MB, Slack E, Hapfelmeier S, Kathy D, McCoy KD, et al. The habitat, double life, citizenship, and forgetfulness of IgA. Immunological Rev. 2012;245:132-46.

108. Tanaka M, Nakayama J. Development of the gut microbiota in infancy and its impact on health in later life. Allergol Int. 2017;66:515-22.

109. Bunker JJ, Flynn TM, Koval JC, Shaw DG, Meisel M, McDonald $\mathrm{BD}$, et al. Innate and adaptive humoral responses coat distinct commensal bacteria with immunoglobulin A. Immunity. 2015;43:541-53.

110. Palm NW, de Zoete MR, Cullen TW, Barry NA, Stefanowski J, Hao L, et al. Immunoglobulin A coating identifies colitogenic bacteria in inflammatory bowel disease. Cell. 2014;158:1000-10.

111. Allan E, Poxton IR, Barclay GR. Anti-bacteroides lipopolysaccharide $\operatorname{IgG}$ levels in healthy adults and sepsis patients. FEMS Immunol Med Microbiol. 1995;11:5-12.

112. Manukyan GP, Ghazaryan KA, Ktsoyan ZA, Khachatryan ZA, Arakelova KA, Kelly D, et al. Elevated systemic antibodies towards commensal gut microbiota in autoinflammatory condition. PLoS ONE. 2008;3:e3172.

113. Haas A, Zimmermann K, Graw F, Slack E, Rusert P, Ledergerber B, et al. Systemic antibody responses to gut commensal bacteria during chronic HIV-1 infection. Gut. 2011;60:1506-19.

114. Cahenzli J, Koller Y, Wyss M, Geuking MB, McCoy KD. Intestinal microbial diversity during early-life colonization shapes long-term IgE levels. Cell Host Microbe. 2013;14: 559-70.

115. Gomez de Agüero M, Ganal-Vonarburg SC, Fuhrer T, Rupp S, Uchimura $\mathrm{Y}, \mathrm{Li} \mathrm{H}$, et al. The maternal microbiota drives early postnatal innate immune development. Science. 2016;351:1296-302.

116. Zeng MY, Cisalpino D, Varadarajan S, Hellman J, Warren HS, Cascalho M, et al. Gut microbiota-induced immunoglobulin $\mathrm{G}$ controls systemic infection by symbiotic bacteria and pathogens. Immunity. 2016;44:647-58.

117. Sedman PC, Macfie J, Sagar P, Mitchell CJ, May J, ManceyJones B, et al. The prevalence of gut translocation in humans. Gastroenterology. 1994;107:643-9.

118. Harmsen HJ, Pouwels SD, Funke A, Bos NA, Dijkstra G. Crohn's disease patients have more IgG-binding fecal bacteria than controls. Clin Vaccin Immunol. 2012;19:515-21.

119. Mohammed N, Tang L, Jahangiri A, de Villiers W, Eckhardt E. Elevated IgG levels against specific bacterial antigens in obese patients with diabetes and in mice with diet-induced obesity and glucose intolerance. Metab: Clin Exp. 2012;61:1211-4.

120. $\mathrm{Li}$ X, Atkinson MA. The role for gut permeability in the pathogenesis of type 1 diabetes-a solid or leaky concept? Pediatr Diabetes. 2015;16:485-92.

121. Michielan A, D'Inca R. Intestinal permeability in inflammatory bowel disease: pathogenesis, clinical evaluation, and therapy of leaky gut. Mediators Inflamm. 2015;2015:628157.

122. Slack E, Hapfelmeier S, Stecher B, Velykoredko Y, Stoel M, Lawson MAE, et al. Innate and adaptive immunity cooperate flexibly to maintain host-microbiota mutualism. Science. 2009;325:617-20.

123. Zimmermann K, Haas A, Oxenius A. Systemic antibody responses to gut microbes in health and disease. Gut Microbes. 2012;3:42-7.

124. Farhadi A, Banan A, Fields J, Keshavarzian A. Intestinal barrier: an interface between health and disease. J Gastroenterol Hepatol. 2013;18:479-97.

125. Rescigno M, Urbano M, Valzasina B, Rotta G, Bonasio R, Granucci F, et al. Dendritic cells express tight junction proteins and penetrate gut epithelial monolayers to sample bacteria. Nat Immunol. 2001;2:361-7.

126. Lelouard H, Fallet M, de Bovis B, Meresse S, Gorvel JP. Peyer's patch dendritic cells sample antigens by extending dendrites through $\mathrm{M}$ cell-specific transcellular pores. Gastroenterology. 2012;142:592-601. e3.

127. Clark MA, Hirst BH, Jepson MA. M-cell surface beta1 integrin expression and invasin-mediated targeting of Yersinia pseudotuberculosis to Mouse Peyer's patch M cells. Infect Immun. 1998;66:1237-43.

128. Peterson DA, McNulty NP, Guruge JL, Gordon JI. IgA response to symbiotic bacteria as a mediator of gut homeostasis. Cell Host Microbe. 2007;2:328-39.

129. Ravindran B, Satapathy AK, Das MK. Naturally-occurring antia-galactosyl antibodies in human Plasmodium falciparum infections - a possible role for autoantibodies in malaria. Immunol Lett. 1988;19:137-42.

130. Yooseph S, Kirkness EF, Tran TM, Harkins DM, Jones MB, Torralba MG, et al. Stool microbiota composition is associated with the prospective risk of Plasmodium falciparum infection. BMC genomics. 2015;16:631-46. 
131. Soares MP, Yilmaz B. Microbiota control of malaria transmission. Trends Parasitol. 2016;32:120-30.

132. Ngwa CJ, Pradel G. Coming soon: probiotics-based malaria vaccines. Trends Parasitol. 2015;31:2-4.

133. Avila JL, Rojas M, Galili U. Immunogenic Gal-a1-3-Gal carbohydrate epitopes are present on pathogenic American Trypanosoma and Leishmania. J Immunol. 1989;142:2828-34.

134. Avila JL, Rojas M, Towbin H. Serological activity against galactosyl-a(1-3)galactose in sera from patients with several kinetoplastida infections. J Clin Microbiol. 1988;26:126-32.

135. Towbin H, Rosenfelder G, Wieslander J, Avila JL, Rojas M, Szarfman A, et al. Circulating antibodies to mouse laminin in Chagas disease, american cutaneous Leishmaniasis, and normal individual recognize terminal galactoysl(a1-3)-galactose epitopes. J Exp Med. 1987;166:419-32.

136. Almeida IC, Milani SR, Gorin PA, Travassos LR. Complementmediated lysis of Trypanosoma cruzi trypomastigotes by human antialpha-galactosyl antibodies. J Immunol. 1991;146:2394-400.

137. Gazzinelli RT. Natural anti-Gai antibodies prevent, rather than cause, autoimmunity in human Chagas' disease. Res Immunol. 1991;142:164-7.

138. Moura APV, Santos LCB, Brito CRN, Valencia E, Junqueira C, Filho AAP, et al. Virus-like particle display of the alpha-gal carbohydrate for vaccination against leishmania infection. ACS Cent Sci. 2017;3:1026-31.

139. Schocker NS, Portillo S, Brito CR, Marques AF, Almeida IC, Michael K. Synthesis of Galalpha(1,3)Galbeta(1,4)GlcNAcalpha-, Galbeta $(1,4)$ GlcNAcalpha- and GlcNAc-containing neoglycoproteins and their immunological evaluation in the context of Chagas disease. Glycobiology. 2016;26:39-50.

140. Hamadeh RM, Jarvis GA, Galili U, Mandrell RE, Zhou P, Griffiss JM. Human natural anti-Gal $\mathrm{IgG}$ regulates alternative complement pathway activation on bacterial surfaces. J Clin Investig. 1992;89:1223-35.

141. Van Nunen SA, O'Connor KS, Clarke LR, Boyle RX, Fernando SL. An association between tick bite reactions and red meat allergy in humans. Med J Aust. 2009;190:510-1.

142. Commins SP, Satinover SM, Hosen J, Mozena J, Borish L, Lewis BD, et al. Delayed anaphylaxis, angioedema, or urticaria after consumption of red meat in patients with $\mathrm{IgE}$ antibodies specific for galactose- $\alpha-1,3$-galactose. J Allergy Clin Immunol. 2009;123:426-33.

143. Commins SP, James HR, Kelly LA, Pochan SL, Workman LJ, Perzanowski MS, et al. The relevance of tick bites to the production of IgE antibodies to the mammalian oligosaccharide galactose- $\alpha-1,3$-galactose. J Allergy Clin Immunol. 2011;127: 1286-93.

144. Araujo RN, Franco PF, Rodrigues H, Santos LCB, McKay CS, Sanhueza CA, et al. Amblyomma sculptum tick saliva: $\alpha-G a l$ identification, antibody response and possible association with red meat allergy in Brazil. Int J Parasitol. 2016;46:213-20.

145. Hilger C, Fischer J, Wölbing F, Biedermann T. Role and mechanism of galactose-alpha-1,3-galactose in the elicitation of delayed anaphylactic reactions to red meat. Curr Allergy Asthma Rep. 2019;19:3.

146. Apostolovic D, Tran TAT, Hamsten C, Starkhammar M, Cirkovic Velickovic T, van Hage M. Immunoproteomics of processed beef proteins reveal novel galactose- $\alpha$-1,3-galactosecontaining allergens. Allergy. 2014;69:1308-15.

147. Chung CH, Beloo Mirakhur B, Emily Chan E, Le Q, Berlin J, Morse $\mathrm{M}$, et al. Cetuximab-Induced anaphylaxis and IgE specific for galactose- $\alpha-1,3$-galactose. N Engl J Med. 2008;358:1109-17.

148. Morisset M, Richard C, Astier C, Jacquenet S, Croizier A, Beaudouin E, et al. Anaphylaxis to pork kidney is related to $\operatorname{IgE}$ antibodies specific for galactose-alpha-1,3-galactose. Allergy. 2012;67:699-704.
149. Steinke JW, Platts-Mills TAE, Commins SP. The alpha-gal story: lessons learned from connecting the dots. J Allergy Clin Immunol. 2015;135:589-96.

150. Saleh H, Embry S, Nauli A, Atyia S, Krishnaswamy G. Anaphylactic reactions to oligosaccharides in red meat: a syndrome in evolution. clinical and molecular. Allergy. 2012;10:5.

151. Damian RT. Molecular mimicry: antigen sharing by parasite and host and its consequences. Am Naturalist. 1964;98:129-49.

152. Moran AP, Prendergast MM, Appelmelk BJ. Molecular mimicry of host structures by bacterial lipopolysaccharides and its contribution to disease. FEMS Immunol Med Microbiol. 1996;16:105-15.

153. Gamian A, Beurret M, Michon F, Brisson JR, Jennings HJ. Structure of the L2 lipopolysaccharide core oligosaccharides Neisseria meningitidis. J Biol Chem. 1992;267:922-5.

154. Michon F, Beurret M, Gamian A, Brisson JR, Jennings HJ. Structure of the L5 lipopolysaccharide core oligosaccharides of Neisseria meninigitidis. J Biol Chem. 1990;265:7243-7.

155. Borrelli S, Roggen EL, Hendriksen D, Jonasson J, Ahmed HJ, Piot $\mathrm{P}$, et al. Monoclonal antibodies against haemophilus lipopolysaccharides: clone DP8 Specific for Haemophilus ducreyi and Clone DH24 binding to lacto-N-neotetraose. Infect Immun. 1995;63:2665-73.

156. Yamasaki R, Bacon BE, Nasholds W, Schneider H, Griffiss JM. Structural determination of oligosaccharides derived from lipooligosaccharide of Neisseria gonorrhoeae F62 by chemical, enzymatic, and two-dimensional NMR methods. Biochemistry. 1991;30:10566-75.

157. Schweda EKH, Sundström AC, Eriksson LM, Jonasson JA, Lindberg AA. Structural studies of the cell envelope lipopolysaccharides from Heamophilus ducreyi strains ITM2665 and ITM4747. J Biol Chem. 1994;269:12040-8.

158. Yamasaki R, Griffiss JM, Quinn KP, Mandrell RE. Neuraminic acid Is a2->3 linked in the lipooligosaccharide of Neisseria meningitidis serogroup B strain 6275. J Bacteriol. 1993;175: 4565-8.

159. Mandrell RE, Kim JJ, John CM, Gibson BW, Sugai JV, Apicella MA, et al. Endogenous sialylation of the lipooligosaccharides of Neisseria meningitidis. J Bacteriol. 1991;173:2823-32.

160. de la Paz H, Cooket SJ, Heckels JE. Effect of sialylation of lipopolysaccharide of Neisseria gonorrhoeae on recognition and complement-mediated killing by monoclonal antibodies directed against different outer-membrane antigens. Microbiology. 1995;141:913-20.

161. Hood DW, Makepeace K, Deadman ME, Rest RF, Thibault P, Martin A, et al. Sialic acid in the lipooligosaccharide of Haemophilus influenzae: strain distribution, influence on serum resistance and structural characterization. Mol Microbiol. 1999;33:679-92.

162. Rutishauser U, Landmesser L. Polysialic acid in the plasticity of the developing and adult vertebrate nervous system. Trends Neurosci. 1996;19:422-7.

163. Schrager HM, Rheinwald JG, Wessels MR. Hyaluronic acid capsule and the role of streptococcal entry into keratinocytes in invasive skin infection. J Clin Investig. 1996;98:1954-8.

164. Wessels MR, Moses AE, Goldberg JB, Dicesare TJ. Hyaluronic acid capsule is a virulence factor for mucoid group A streptococci. Proc Natl Acad Sci USA. 1991;88:8317-21.

165. Garantziotis S, Savani RC. Hyaluronan biology: a complex balancing act of structure, function, location and context. Matrix Biol. 2019;78-79:1-10.

166. Aspinall GO, Monteiro M. Lipopolysaccharides of Helicobacter pylori strains $\mathrm{P} 466$ and MO19: structures of the O antigen and core oligosaccharide regions. Biochemistry. 1996;35:2498-504.

167. Brockhausen I. Crossroads between bacterial and mammalian glycosyltransferases. Front Immunol. 2014;5:492. 
168. Bouchet V, Hood DW, Li J, Brisson JR, Randle GA, Martin A, et al. Host-derived sialic acid is incorporated into Haemophilus influenzae lipopolysaccharide and is a major virulence factor in experimental otitis media. Proc Natl Acad Sci USA. 2003;100:8898-903.

169. Hooper LV, Xu J, Falk PG, Midtvedt T, Gordon JI. A molecular sensor that allows a gut commensal to control its nutrient foundation in a competitive ecosystem. Proc Natl Acad Sci USA. 1999;96:9833-8.

170. Coyne MJ, Reinap B, Lee MM, Comstock LE. Human symbionts use a host-like pathway for surface fucosylation. Science. 2005;307:1778-81.

171. Ang CW, Jacobs BC, Laman JD. The Guillain-Barre syndrome: a true case of molecular mimicry. Trends Immunol. 2004;25:61-6.

172. Olive J, Castillo C, Garcia Castro R, de Quadros CA. Epidemiologic study of Guillain-Barre syndrome in children $<15$ years of age in Latin America. J Infect Dis. 1997;175(Suppl 1): S160-4.

173. Hahn AF. Guillain-Barré syndrome. Lancet. 1998;352:635-41.

174. Yu RK, Usuki S, Ariga T. Ganglioside molecular mimicry and its pathological roles in Guillain-Barre syndrome and related diseases. Infect Immun. 2006;74:6517-27.

175. Epps SV, Harvey RB, Hume ME, Phillips TD, Anderson RC, Nisbet DJ. Foodborne Campylobacter: infections, metabolism, pathogenesis and reservoirs. Int $\mathrm{J}$ Environ Res Public Health. 2013;10:6292-304.

176. Hadden RD, Karch H, Hartung HP, Zielasek J, Weissbrich B, Schubert $J$, et al. Preceding infections, immune factors, and outcome in Guillain-Barré syndrome. Neurology. 2001;56: 758-65.

177. Aspinall GO, Fujimoto S, McDonald AG, Pang H, Kurjanczyk LA, Penner JL. Lipopolysaccharides from Campylobacter jejuni associated with Guillain-Barre syndrome patients mimic human gangliosides in structure. Infect Immun. 1994;62:2122-5.

178. Yuki N. Molecular mimicry between gangliosides and lipopolysaccharides of Campylobacter jejuni isolated from patients with Guillain-Barre Miller Fisher syndrome. J Infect Dis. 1997;176(Suppl 2):S150-3.

179. Yuki N, Susuki K, Koga M, Nishimoto Y, Odaka M, Hirata K, et al. Carbohydrate mimicry between human ganglioside GM1 and Campylobacter jejuni lipooligosaccharide causes GuillainBarre syndrome. Proc Natl Acad Sci USA. 2004;101:11404-9.

180. Moran AP, Prendergast MM. Molecular mimicry in Campylobacter jejuni and Helicobacter pylori lipopolysaccharides: contribution of gastrointestinal infections to autoimmunity. J Autoimmun. 2001;16:241-56.

181. Schwerer B. Antibodies against gangliosides: a link between preceding infection and immunopathogenesis of Guillain-Barré syndrome. Microbes Infect. 2002;4:373-84.

182. Moran AP, Annuk H, Prendergast MM. Antibodies induced by ganglioside-mimicking Campylobacter jejuni lipooligosaccharides recognise epitopes at the nodes of Ranvier. J Neuroimmunol. 2005;165:179-85.

183. Reynolds R, Roncaroli F, Nicholas R, Radotra B, Gveric D, Howell $\mathrm{O}$. The neuropathological basis of clinical progression in multiple sclerosis. Acta Neuropathol. 2011;122:155-70.

184. Harris VK, Sadiq SA. Biomarkers of therapeutic response in multiple sclerosis: current status. Mol Diagnosis Ther. 2014;18:605-17.

185. Arnon R, Crisp E, Kelley R, Ellison GW, Myers LW, Tourtellotte WW. Anti-ganglioside antibodies in Multiple Sclerosis. J Neurol Sci. 1980;46:179-86.

186. Endo T, Scott DD, Stewart SS, Kundu SK, Marcus DM. Antibodies to glycosphingolipids in patients with multiple sclerosis and SLE. J Immunol. 1984;132:1793-7.
187. Schwarz M, Spector L, Gortler M, Weisshaus O, Glass-Marmor L, Karni A, et al. Serum anti-Glc(alpha1,4)Glc(alpha) antibodies as a biomarker for relapsing-remitting multiple sclerosis. J Neurol Sci. 2006;244:59-68.

188. Menge T, Lalive PH, von Budingen HC, Cree B, Hauser SL, Genain $\mathrm{CP}$. Antibody responses against galactocerebroside are potential stage-specific biomarkers in multiple sclerosis. J Allergy Clin Immunol. 2005;116:453-9.

189. Grader-Beck T, Boin F, von Gunten S, Smith D, Rosen A, Bochner BS. Antibodies recognising sulfated carbohydrates are prevalent in systemic sclerosis and associated with pulmonary vascular disease. Ann Rheum Dis. 2011;70:2218-24.

190. Paul S, Boschetti G, Rinaudo-Gaujous M, Moreau A, Del Tedesco E, Bonneau J, et al. Association of anti-glycan antibodies and inflammatory bowel disease course. J Crohn's Colitis. 2015;9:445-51.

191. Kaul A, Hutfless S, Liu L, Bayless TM, Marohn MR, Li X. Serum anti-glycan antibody biomarkers for inflammatory bowel disease diagnosis and progression: a systematic review and metaanalysis. Inflamm Bowel Dis. 2012;18:1872-84.

192. Rieder F, Schleder S, Wolf A, Dirmeier A, Strauch U, Obermeier F, et al. Association of the novel serologic anti-glycan antibodies anti-laminarin and anti-chitin with complicated Crohn's disease behavior. Inflamm Bowel Dis. 2010;16:263-74.

193. Dotan I, Fishman S, Dgani Y, Schwartz M, Karban A, Lerner A, et al. Antibodies against laminaribioside and chitobioside are novel serologic markers in Crohn's disease. Gastroenterology. 2006;131:366-78.

194. Kappler K, Lasanajak Y, Smith DF, Opitz L, Hennet T. Increased antibody response to fucosylated oligosaccharides and fucose-carrying Bacteroides species in Crohn's disease. Front Microbiol. 2020;11:1553

195. Dai H, Li Z, Zhang Y, Lv P, Gao XM. Elevated levels of serum antibodies against Saccharomyces cerevisiae mannan in patients with systemic lupus erythematosus. Lupus. 2009;18:1087-90.

196. Dotta F, Previti M, Neerman-Arbez M, Dionisi A, Cucinotta D, Lenti L, et al. The GM2-1 ganglioside islet autoantigen in insulin-dependent diabetes mellitus is expressed in secretory granules and is not-cell specific. Endocrinology. 1998;139: 316-9.

197. Gillard BK, Thomas JW, Nell LJ, Marcus DM. Antibodies against ganglioside GT3 in the sera of patients with type I diabetes mellitus. J Immunol. 1989;142:3826-32.

198. Cunningham MW. Autoimmunity and molecular mimicry in the pathogenesis of post-streptococcal heart disease. Front Biosci. 2003;8:s533-43.

199. Mende M, Bordoni V, Tsouka A, Loeffler FF, Delbianco M, Seeberger PH. Multivalent glycan arrays. Faraday Discuss. 2019;219:9-32.

200. Schena M, Shalon D, Davis RW, Brownt PO. Quantitative monitoring of gene expression patterns with a complementary DNA microarray. Science. 1995;270:467-70.

201. Fazio F, Bryan MC, Blixt O, Paulson JC, Wong CH. Synthesis of sugar arrays in microtiter plate. $\mathrm{J}$ Am Chem Soc. 2002;124:14397-402.

202. Houseman BT, Mrksich M. Carbohydrate arrays for the evaluation of protein binding and enzymatic modification. Chem Biol. 2002;9:443-54.

203. Wang D. Carbohydrate microarrays. Proteomics. 2003;3: 2167-75.

204. Geissner A, Seeberger PH. Glycan arrays: from basic biochemical research to bioanalytical and biomedical applications. Annu Rev Anal Chem. 2016;9:223-47.

205. Song X, Heimburg-Molinaro J, Cummings RD, Smith DF. Chemistry of natural glycan microarrays. Curr Opin Chem Biol. 2014;18:70-7. 
206. Song X, Lasanajak Y, Xia B, Heimburg-Molinaro J, Rhea JM, Ju $\mathrm{H}$, et al. Shotgun glycomics: a microarray strategy for functional glycomics. Nat methods. 2011;8:85-90.

207. Blixt O, Head S, Mondala T, Scanlan C, Huflejt ME, Alvarez R, et al. Printed covalent glycan array for ligand profiling of diverse glycan binding proteins. Proc Natl Acad Sci USA. 2004;101:17033-8.

208. Parthasarathy N, DeShazer D, England M, Waag DM. Polysaccharide microarray technology for the detection of Burkholderia pseudomallei and Burkholderia mallei antibodies. Diagnostic Microbiol Infect Dis. 2006;56:329-32.

209. Blixt O, Hoffmann J, Svenson S, Norberg T. Pathogen specific carbohydrate antigen microarrays: a chip for detection of Salmonella O-antigen specific antibodies. Glycoconj J. 2008;25: $27-36$.

210. Jacob F, Goldstein DR, Bovin NV, Pochechueva T, Spengler M, Caduff $\mathrm{R}$, et al. Serum antiglycan antibody detection of nonmucinous ovarian cancers by using a printed glycan array. Int $\mathbf{J}$ Cancer. 2012;130:138-46.

211. Lawrie CH, Marafioti T, Hatton CSR, Dirnhofer S, Roncador G, Went $\mathrm{P}$, et al. Cancer-associated carbohydrate identification in Hodgkin's lymphoma by carbohydrate array profiling. Int $\mathbf{J}$ Cancer. 2006;118:3161-6.

212. Geissner A, Anish C, Seeberger PH. Glycan arrays as tools for infectious disease research. Curr Opin Chem Biol. 2014;18: $38-45$.

213. Martin CE, Broecker F, Oberli MA, Komor J, Mattner J, Anish C, et al. Immunological evaluation of a synthetic clostridium difficile oligosaccharide conjugate vaccine candidate and identification of a minimal epitope. J Am Chem Soc. 2013;135:9713-22.

214. Byrd-Leotis L, Jia N, Dutta S, Trost JF, Gao C, Cummings SF, et al. Influenza binds phosphorylated glycans from human lung. Sci Adv. 2019;5:eaav2554.

215. Stevens J, Blixt O, Glaser L, Taubenberger JK, Palese P, Paulson $\mathrm{JC}$, et al. Glycan microarray analysis of the hemagglutinins from modern and pandemic influenza viruses reveals different receptor specificities. J Mol Biol. 2006;355:1143-55.
216. Zhao N, Martin BE, Yang C, Luo F, Wan X. Association analyses of large-scale glycan microarray data reveal novel hostspecific substructures in influenza A virus binding glycans. Sci Rep. 2015;5:15778.

217. Gulati S, Lasanajak Y, Smith DF, Cummings RD, Air GM, Marino PA. Glycan array analysis of influenza H1N1 binding and release. Cancer Biomark. 2014;14:43-53.

218. Hsu KL, Mahal LK. Sweet tasting chips: microarray-based analysis of glycans. Curr Opin Chem Biol. 2009;13: 427-32.

219. Salvadori LG, Blake MS, McCarty M, Tai JY, Zabriskie JB. Group A streptococcus-liposome ELISA antibody titers to group A polysaccharide and opsonophagocytic capabilities of the antibodies. J Infect Dis. 1995;171:593-600.

220. Pochechueva T, Jacob F, Goldstein DR, Huflejt ME, Chinarev A, Caduff $\mathrm{R}$, et al. Comparison of printed glycan array, suspension array and ELISA in the detection of human anti-glycan antibodies. Glycoconj J. 2011;28:507-17.

221. Pochechueva T, Chinarev A, Spengler M, Korchagina E, Heinzelmann-Schwarz V, Bovin N, et al. Multiplex suspension array for human anti-carbohydrate antibody profiling. Analyst. 2011;136:560-9.

222. Briard JG, Jiang H, Moremen KW, Macauley MS, Wu P. Cellbased glycan arrays for probing glycan-glycan binding protein interactions. Nat Commun. 2018;9:880.

223. Lapebie P, Lombard V, Drula E, Terrapon N, Henrissat B. Bacteroidetes use thousands of enzyme combinations to break down glycans. Nat Commun. 2019;10:2043.

224. Mimee M, Tucker AC, Voigt CA, Lu TK. Programming a human commensal bacterium, bacteroides thetaiotaomicron, to sense and respond to stimuli in the murine gut microbiota. Cell Syst. 2015;1:62-71.

225. Celik E, Ollis AA, Lasanajak Y, Fisher AC, Gur G, Smith DF, et al. Glycoarrays with engineered phages displaying structurally diverse oligosaccharides enable high-throughput detection of glycan-protein interactions. Biotechnol J. 2015;10:199-209. 